From the Department of Child Health, Medical School, University of Gajah Mada, Yogyakarta

\section{Congenital Adrenal Hyperplasia (Case Report)}

by

\section{MARWOTO and ACHMAD SURJONO}

\section{Abstract}

A case of a female infant with congenital abnormality of the urogenital apparatus, an excess of the urinary 17-ketosteroid, mild salt losing disorder, acceleration of growth ossification, described as congenital adrenal hyperplasia due to 21-hydroxylase defect has been reported.

Received 2nd. Feb. 1976.

\section{Introduction}

The adrenal cortex secretes a variety of steroid hormones including: androgens (17-ketosteroid), aldosterone (a salt retaining hormone), compound $\mathrm{F}$ (hydrocortisone, cortisol), which is closely related to cortisone and formerly known as "sugar hormone" (Bongiovanni and Eberlein, 1955).

The adrenogenital syndrome due to congenital adrenal hyperplasia, is considered an inborn error of metabolism. Hyperplasia may be of unknown etiology, but in most cases it results from inborn deficiency of enzymes for biosynthesis of cortisol (Hughes, 1971).

The deficiency of cortisol, a potent inhibitor of pituitary activity results in hyperproduction of corticotropin, which ultimately leads to adrenocortical hyperplasia and hyperproduction of androgens as reflected by high secretion of 17 ketosteroid in urine. The various disturbances in the synthesis of cortisol and related glucocorticoids resulting in an accumulation of 17-hydroxyprogesterone in the body, in turn, serve as precursor for a number of 17-ketosteroids with variable androgenic potency. This fraction is responsible for masculinisation.

The disorder is initiated in utero. The androgenic effect usually manifests in females between the $3 \mathrm{rd}$ and 5 th month of fetal life i.e., after the occurrence of the sexual differentiation of gonad and genital duct and before the formation of separate urethral and vaginal tubes. The earlier the androgenic activity begins in fetal life, the more pronounced will be the external virilization (Iverson, 1955).

Bongiovanni and Eberlein (1955) stated that infants with cortical adrenal hyperplasia become virilized (pseudo hermaphroditism in the female, macrogenitosomia praecox in the male) and in a few cases in addition one of the following complications :

a. addisonian-like state with salt loss, dehydration, circulatory collapse, leading to death in early infancy.

b. hypertension.

c. rarely, hypoglycemia.

Deficiency of enzymes such as 21-hydroxylase, 11-beta-hydroxylase, 3-betahydroxysteroid dehydrogenase, 17-hydroxylase and desmolase are associated with congenital adrenal hyperplasia (New, 1968). Approximately 90 per cent of patients with congenital adrenal hyperplasia have defect in 21-hydroxylation (Nelson, 1969).

Cases of congenital adrenal hyperplasia have rarely been reported in Indonesia. The first case has been described by Oen et al. (1968), the second by Jusuf and Oen (1969) and this case is probably the third.

\section{Case Report}

History of the patient.

The patient, a fullterm infant, was delivered on July 23, 1972, in Bethesda Hospital, Yogyakarta. The pregnancy of the mother was uneventful. Administration of progesterone-like drugs during this period was not noted. Heredi- 
tary disorders were unknown in either parents. The baby was born by vacuum extraction; at birth the only apparent abnormality was the urogenital apparatus.

I. Physical examination during neonatal period:

Birth weight and length were 2810 gm and $49 \mathrm{~cm}$, circumference of head and chest were $34 \mathrm{~cm}$ and $33 \mathrm{~cm}$ respectively. On examination the baby appeared to be in a good condition, active, reddish and had a good turgor. Blood pressure could not be determined. External genitalia: the clitoris was about $1 \mathrm{~cm}$, hypertrophic giving the appearance of hypospadic penis and rugosity of labia resembled a scrotum.

Examination of internal genitalia was not done. X-ray visualization of the vagina was unsuccessful due to technical difficulty. Cystography: the bladder was normal, the external orifice of the urethra however could not be detected. The orifice below the clitoris could be the common opening of the vagina and urethra.

On the 4th day after birth, the body weight decreased to $2580 \mathrm{gm}$, there were signs and symptoms of icterus neonatorum. The infant had received adequate amounts of mother's breast milk. At 12 days of age, the body weight was 2680 $\mathrm{gm}$, the baby was lazy, the skin was rather dry although there were no signs of salt and water loss.

The parents insisted on taking the baby home, when their baby was 15 days of age with a body weight of 2775 gm. The baby had not been treated due to technical difficulties in determination of urinary 17 -ketosteroid.

\section{Laboratory findings.}

1. Nuclear sexing of the buccal smear was positive for sex chromatine.

2. The baby's urine was sent to the Department of Biochemistry of the University of Indonesia for urinary 17-ketosteroid and 17-hydroxycorticosteroids determinations, but unfortunately this urine could not be examined due to its poor condition upon arrival in Jakarta.

3. Hb. was $12.6 \mathrm{gm} \%$, Hematocrit was $34 \%$.

II. On October 2, 1972, for the second time the baby was admitted to the Bethesda Hospital for further examination. The baby was then 70 days of age with a body weight of $2880 \mathrm{gm}$ and a length of $52 \mathrm{~cm}$.

The baby sometimes vomited, there were no diarrhea, signs and symptoms of dehydration nor loss of body weight. The baby had a rather dry skin, howe. ver, there was a slight increase of body weight, though the mother's milk was adequte. Röntgenography of the hand showed an acceleration of growth of the primary and secondary ossification of the hand, resembling that of a normal one year old baby. At 73 days of age, the body weight was 2800 gms, the baby was inactive, pale, the skin turgor was moderate. There were no dehydration and diarrhea.
After blood transfusion and cortisone injection $10 \mathrm{mg} /$ day, the baby's condition and activity improved. At the age of 81 days, the body weight became $3000 \mathrm{gm}$ the parents refused further hospitalization and oral administration c.t cortisone $15 \mathrm{mg} /$ day was continued.

Laboratory findings :

1. $\mathrm{Hb}: 8 \mathrm{gm} \%$

Hematocrit : $26 \%$ (before blood tranfusion).

2. Urine examination

The 24 hours excretion of 17 -ketosteroid was $4.4 \mathrm{gm}$. and 17 -hydroxycorticosteroids was $0.59 \mathrm{mg}$.

3. Serum sodium and potassium:

$$
\begin{array}{c:cc}
\mathrm{Na} & : 281.6 & \mathrm{mg} \% \\
\mathrm{~K} & : 28.61 & \mathrm{mg} \% \\
\mathrm{Cl} & : 530 & \mathrm{mg} \% \\
\multicolumn{3}{c}{\text { Discussion }}
\end{array}
$$

\section{Discussion}

Congenital adrenal hyperplasia due to 21-hydroxylase defect is divided into mild and severe forms. The diagnosis of the mild form of congenital adrenal hyperplasia is established by :

a. virilization in utero.

b. the absence of hypertension and electrolyte disturbance.

c. increase of the urinary 17-ketosteroid

(Hsia, 1968; New, 1968; Williams, 1967).

In this case :

1. The infant had congenital abnormality of the urogenital apparatus (hypertrophy of the clitoris and rugosity of the labia resembling a scrotum) and the nuclear sexing of the buccal smear revealed a positive sex chromatine; so this case was a female pseudohermaphrodite.

2. a. Blood pressure could not be measured.

b. The baby sometimes vomited, without signs and symptoms of dehydration, loss of weight, diarrhea.

Serum sodium was $281.6 \mathrm{mg} \%$, serum potassium was 28.61 $\mathrm{mg} \%$, serum chloride was 530 $\mathrm{mg} \%$.

The absence of addisonian-like state, with low concentration of sodium and elevation of potassium level indicated a mild salt losing disorder.

3. The urinary 17 -ketosteroid was 4.4 $\mathrm{mg} / 24$ hours (normal : $0.5-2.5$ $\mathrm{mg} / 24$ hours).

Thus in this case there was an elevated level of urinary 17 -ketosteroid.

\section{REFERENCES}

1. ABDOES, S. and MOELJONO, D.: The determination of chromosomal sex by oral smear. Maj. Kedok. Indones. 4: 190 (1961).
2. BONGIOVANNI, A.M. and EBERLEIN, W.R. : Clinical and metabolic variations in adrenogenital syndrome. Pediatrics 16 : 628 (1955). 
3. HSIA, Y.Y.D. : Inborm error of metabolism; part I, second Ed. pp. 245 255 (Yearb. med. Publ.., Chicago 1968).

4. HUGHES, J.G. : Synopsis of pediatrics, 3rd Ed. (Mosby St. Louis, 1971).

5. IVERSON, T. : Congenital adrenocortical hyperplasia with disturbances of electrolyte regulation. Pediatrics 16 : 875 (1955).

6. JUSUF, S.M. and OEN, L.H. : Congenital adrenal hyperplasla. Paediatr. Indones. 9 : 36 (1969).
7. NELSON, W.E. : Textbook of pediatrics 9th Ed. pp. 1211 - 1220. (Igaku Shoin, Tokyo 1969).

8. NEW, I.M. : Congenital adrenal hyperplasia. Pediatr. Clin North America 4 : 395 (1968).

9. OEN, L.H., KOENTARIAH, S., ABDULLAH, H.: Congenital Adrenal hyperplasla due to C21-hydroxylase defect. Paediatr. Indones. $8: 154$ (1968).

10. WILLIAMS : Textbook of endocrinology. 3rd. Ed. pp. $359-369$. (Saunders, Philadelphia/London 1967). 